\title{
СПЕЦИФИКА ЛЕКСИЧЕСКОЙ СОСТАВЛЯЮЩЕЙ ВОЕННО-ПОЛИТИЧЕСКОГО ДИСКУРСА ОДКБ
}

\section{LEXICAL DISTINCTIVE FEATURES OF MILITARY-POLITICAL DISCOURSE OF THE CSTO}

\section{Fedotov}

Summary: The article is devoted to the distinctive features of militarypolitical discourse of the Collective Security Treaty Organization (CSTO). The approaches of researchers to the study of this type of discourse are considered. The linguistic analysis of military-political discourse based on the documents of the CSTO is carried out. Lexical features inherent in the texts of the international documents of the CSTO are revealed.

Keywords: theory of language, discourse, military-political discourse, the CSTO, CSTO documents, lexical features.

\author{
Федотов Илья Игоревич \\ Преподаватель, Военный университет (2. Москва) \\ ilyafed55@gmail.com
}

Аннотация: Статья посвящена особенностям военно-политического дискурса Организации Договора о коллективной безопасности (ОДКБ). Рассматриваются подходы исследователей к изучению данного типа дискурса. Анализируется военно-политический дискурс на основе документов ОДКБ с точки зрения лингвистических особенностей. Выявлены лексические особенности, присущие текстам международных документов ОДКБ.

Ключевые слова: слова: теория языка, дискурс, военно-политический дискурс, ОДКБ, документы ОДКБ, лексические особенности.

Киселева С.А. считает, что данный вид дискурса стоит рассматривать как разновидность мультимедийного дискурса. Под понятием «мультимедийный дискурс» исследователь понимает дискурс разнообразных средств массовой информации [3].

Хомутова Т.Н., Наумова К.А. подчеркивают, что военно-политический дискурс имеет интегративный характер, но в то же время обладает специфическими чертами, поэтому в типологии дискурса у него должно быть особое положение, которое является самостоятельным в ряду военного и политического дискурсов [10]. Аналогичного взгляда придерживаются и другие исследователи, в частности, Мошкина Ю.В. [7], Мавлеев Р.Р. [5]. Автор статьи также является сторонником данного подхода.

Особый интерес предоставляют собой тексты военно-политического дискурса такой международной организации, как Организации Договора о коллективной безопасности (ОДКБ), поскольку данный военнополитический блок является наиболее молодым среди мировых коллективных структур безопасности, а также в среде многостороннего военно-политического сотрудничества. Часть исследователей представляют ОДКБ в качестве перспективного проекта в сфере региональной безопасности, и даже более того, как элемент будущей континентальной системы в больших масштабах [1], что будет выступать в качестве существенного экстралингвистического фактора, определяющего лингвистические характеристики военно-политического дискурса.

Организация Договора о коллективной безопас- 
ности была учреждена 14 мая 2002 года; в настоящее время (2021 год) членами ОДКБ являются шесть стран: Армения, Белоруссия, Казахстан, Киргизстан, Россия и Таджикистан.

На сегодняшний день в рамках ОДКБ состоялось подписание 48 международных договоров [8]. Тексты этих договоров регламентируют основные направления межгосударственной коммуникации и определяют тенденции в сотрудничестве государств-участников этой организации. В целом, тексты основных документов, действующих в рамках ОДКБ, могут быть классифицированы по трем подгруппам:

1. тексты Договора основания и Устава ОДКБ;

2. тексты Соглашений ОДКБ;

3. тексты Протоколов ОДКБ.

Проведенный анализ комплекса документации ОДКБ позволяет предположить, что тексты данных документов на ряду с другими лингвистическими характеристиками имеют свою, присущую только им специфику использования лексических средств. Прежде всего можно отметить применение значительного количества терминов, которые в достаточной мере находят употребление в различных сферах международного военного сотрудничества. Такие термины относятся к политике, социальной сфере, экономике, медицине и к иным направлениям межгосударственного взаимодействия. Как правило, определенный термин при составлении текста документа выбирается в зависимости от предмета того или иного международного договора.

В текстах международных документов ОДКБ мы можем наблюдать присутствие значительного количества аббревиатур. Для примера рассмотрим текст Соглашения о миротворческой деятельности Организации Договора о коллективной безопасности [9], где выявляется следующие сокращенные написания группы слов:

«В Уставе ООН..., ... решениям Совета Безопасности $\mathrm{OОН}, \ldots$ участие ОДКБ, ... КМС, ... СКБ, ... СМИД, СМО и KССБ».

В документах ОДКБ имеется такая особенность, как введение точной дефиниции определенных терминов непосредственно в текст самого документа. Таким образом, просматривается, что составители текстов документов ОДКБ стремятся к максимальному ограничению многозначности слов и достижению достаточно узкой терминологизации, которая охватывает широкий спектр используемых лексических языковых средств. Так, в Соглашении о миротворческой деятельности Организации Договора о коллективной безопасности [9] встречаются такие определения, как:

«миротворческая деятельность ОДКБ» - совокупность мер, включающих ...»;

«миротворческие контингенты государств-членов
ОДКБ»... - специально подготовленный ... персонал ...».

В текстах договоров ОДКБ присутствуют ссылки на коммуникантов, а именно участников и функционеров, деятельность которых, как правило, связана с международными общественными организациями. Достаточно частотно применяются следующие термины: «государства-участники», «государства-члены», «стороны», «член организации», «секретариат», «представители», «уполномоченные органы», «сотрудники», «должностные лица», «генеральный секретарь».

Для текстов договоров ОДКБ характерно применение интернациональной лексики, при этом по большей части такие слова имеют латинское происхождение: «организация» - от лат. "organize" [2, с. 938], «реализация»от лат. "realis" [2, с. 1108].

В ходе исследования лексических особенностей, характерных для текстов международных договоров ОДКБ, выявилась такая особенность, как значительная насыщенность указанных текстов клише и штампами, достаточно часто воспроизводимыми в официально-деловых документах. Указанные стереотипные словосочетания, как правило, обладают абстрактными значениями и оценочными свойствами, носящими социально закрепленный, в некоторой мере традиционный характер.

Взяв за основу классификацию стереотипных словосочетаний в международных документах исследователя Мадоновой A.B. [6], применительно к текстам договоров ОДКБ могут быть выделены следующие лексические группы:

1. Обороты, характерные для официально-канцелярского стиля:

«согласились о нижеследующем», «Протокол действует», «обращение направляется», «направив письменное уведомление».

2. Клише и штампы, характерные для общей тематики: "военно-политическое сотрудничество», "оказание содействия», «в интересах обеспечения», «эффрективность деятельности», «обмен информачией».

3. Обороты, характерные для экономической направленности: «иное имущество», «несут расходы»».

4. Обороты, которые относятся к деятельности общественного характера: «совместная деятельность», «межправительственные организации».

Текстам документов ОДКБ свойственно наличие клише как с положительной коннотацией («сотрудничать с государствами», «в тесном сотрудничестве»), так и клише с отрицательной коннотацией («телесным повреждением», «деструктивное воздействие», «дорожно-транспортным происшествием»). При этом можно также наблюдать применение ограниченного набора 
глаголов, окрашенных эмоционально нейтрально («договорились», «согласились»), отглагольных существительных («исполненные решимости»), деепричастий («подтверждая», «руководствуясь», «действуя», «стремясь»). Использование данных частей речи преимущественно свойственно для официально-делового стиля. Основная часть глаголов указывает на тему предписания и долженствования.

Необходимо отметить, что в текстах документов ОДКБ применяются слова и словосочетания, свойственные литературному языку, и имеющие достаточно ярко выраженную функционально-стилистическую окраску: «правосудие», «юридическое лицо», «юрисдикция».

Таким образом, по результатам анализа лексических особенностей текстов документации военно-политического дискурса Организации Договора о коллективной безопасности можно сделать следующие выводы. В тексты международных договоров ОДКБ включены различные виды лексики (общеупотребительная, специализированная, терминологическая и др.,), которая несёт тексто- и стилеобразующую функции. Подготовка и составление данных текстов требует адекватного использования лексических средств с той целью, чтобы в достаточно большой мере уменьшить неясности и разночтения текстов документов ОДКБ. Данные тексты имеют такие лексические особенности, как высокая частота применения клише и штампов, относящихся, прежде всего, к официально-канцелярским, наличие интернациональной лексики, а также лексических единиц, которые имеют оценочную коннотацию.

\section{ЛИТЕРАТУРА}

1. Алиев Н.Т., Романова В.В. ОДКБ: проблемы и перспективы // Материалы ХІІ Международной студенческой научной конференции «Студенческий научный форум». 2020. URL: https://scienceforum.ru/2020/article/2018021355 (дата обращения: 19.10.2021).

2. Большой энциклопедический словарь / Гл. ред. А.М. Прохоров. М. : Сов. энцикл., 1993. 1628 с.

3. Киселева С.А. Функционирование эвфемизмов в современном английском военно-политическом дискурсе (структурно-семантический и прагматический аспекты): специальность 10.02.04 «Германские языки»: диссертация на соискание ученой степени кандидата филологических наук; Московский педагогический государственный университет. Москва, 2015. 240 с.

4. урббаков И.А. Военно-политический дискурс как гибридный тип дискурса // Достижения науки в контексте повышения качества жизни и устойчивого развития общества : Сборник научных статей международной научно-практической конференции и IV Всероссийской (с международным участием) конференции, Алматы, 29 апреля 2019 года / Под общей редакцией А.А. Арупова. Алматы: Национальный исследовательский институт мировой экономики и международных отношений имени Е.М. Примакова Российской академии наук, 2019. С. 210-217.

5. Мавлеев Р.Р. Военно-политический дискурс: социально-коммуникативные, лингвокогнитивные и переводческие аспекты (на материале китайского и русского языков) : специальность 10.02.20 «(равнительно-историческое, типологическое и сопоставительное языкознание» : диссертация на соискание ученой степени кандидата филологических наук ; Военный университет. Москва, 2019. 246 с.

6. Мадонова А.В. Лексические особенности текстов международных договоров (на материале параллельных русско-французских текстов) // ОгарёвOnline. 2016. № 6 (71). C. 1-5. URL: http://journal.mrsu.ru/arts/leksicheskie-osobennosti-tekstov-mezhdunarodnyx-dogovorov-na-materiale-parallelnyx-russkofrancuzskix-tekstov (дата обращения: 19.10.2021).

7. Мошкина Ю.В. Структурно-содержательные особенности военно-политического дискурса: теоретические аспекты // Антропоцентрическая направленность лингвистических исследований поликультурного военного и политического дискурса / Под научной редакцией В.Н. Бабаяна; Ярославское высшее военное училище противовоздушной обороны. Ярославль : 000 «Цифровая типография», 2020. С. 123-131.

8. Правовая база ОДКБ // Организация договора о коллективной безопасности : официальный сайт. 2012. URL: https:// https://odkb-csto.org/documents/ documents/pravovaya_baza_odkb/ (дата обращения: 19.10.2021)

9. Соглашение о миротворческой деятельности Организации Договора о коллективной безопасности от 6 октября 2007 г. // Организация Договора 0 коллективной безопасности: официальный сайт. 2013. URL: https://odkb-csto.org/documents/documents/soglashenie_0_mirotvorcheskoy_deyatelnosti_ organizatsii_dogovora_0_kollektivnoy_bezopasnosti/(дата обращения: 19.10.2021).

10. Хомутова Т.Н., Наумова К.А. Военно-политический дискурс как особый тип дискурса // Вестник Южно-Уральского государственного университета. Серия: Лингвистика. 2017. Т. 14. № 3. С. 49-53. 